\title{
Economy and Politics in the Embargo of High Technology during the Cold War. The Case of a Semi Peripheral Country (Spain)*
}

\author{
Ángel Calvo \\ University of Barcelona \\ Spain
}

\begin{abstract}
The political reasons lying on far-reaching economic decisions making has been at the center of international debate for many years, especially during the Cold War. This article aims to deepen the understanding of the functioning of the world economy during the Cold War. It analyzes the scope of policies to control the transfer of Western high technology to enemy countries in the framework of a division of the world into blocs. In particular, it is proposed to examine the mechanisms of the technological embargo imposed by the hegemonic power in the West -US- and its economic repercussions on several Spanish companies of the high-end sectors. This contribution adopts an interdisciplinary perspective that combines the economic approach of Adler-Karlsson (1968), the most general of the geo-economics and the business of Segreto (2006). The work diversifies and updates the bibliography and incorporates new primary sources, including business and official sources.
\end{abstract}

Keywords: High technology transfer, CoCom, Cold War, exports control.

\section{Introduction}

Just as protecting the United States and its citizens from any harm by means consistent with the idiosyncrasy of the nation -values, laws and way of life- has been an inseparable goal of the country's history, exploring the eternal dilemma amongst national security and economic development has been a recurrent issue for academics ${ }^{1}$. Thus, scholars from different disciplines have devoted numerous contributions to one of the episodes -the Cold War-. On the contrary, economic and business historians have paid to it little attention as such ${ }^{2}$. This paper focuses primarily on one of the key pieces in the maintenance of national security - the Coordinating Committee for Multilateral Export Controls (CoCom). It explores the bases of the imperial domination of the USA through the scrutiny of the mechanisms and effects of controlling the transfer of knowledge and high technology amongst Western and non-Western countries during the Cold War.

It fits into the quantitative approach of Adler-Karlsson (1968) in its pioneer aspect or other subsequent studies (Jones and Karreth, 2010), as well as in the interdisciplinary approach of Segreto (2006). From the study of Spanish cases, it validates the statements of some specialists (Buesa, 2000) on the control of international exchanges of dual-use technologies and weapons as a variant of protectionism and an instrument for maintaining economic supremacy and Western leadership technological ${ }^{3}$.

From the methodological point of view, the study aims to cover the different forms and levels of the transfer, ranging from commercial operations to less conventional forms of technology mobility. In terms of geographic scope and direction of the flows, it includes movements from a peripheral country in the western area to countries of the opposite bloc and from a multinational company of a western power to that peripheral country.

\footnotetext{
*The current version is assigned to the project HAR2015-64769-P. Advances of this research were presented at four international conferences (The 2017 ISESS, Bali, Indonesia, January 19-21, 2017; ENTRENOVA, Dubrovnik, Croatia, September 7-9, 2017; EBES Conference, January 10-12, 2018, Bangkok, Thailand and International Institute of Social and Economic Sciences, 40th International Academic Conference, June 25-28, 2018, Stockholm, Sweden). I thank the organizers for the acceptance of the papers and the attendees for their comments. A preliminary version was published at Biblio $3 \mathrm{~W}$, 1.230, March 15, 2018.

${ }^{1}$ Two chronologically extreme references: Barnett (1960), pp. 36-49; Asghari (2017), pp. 905-924.

${ }^{2}$ Higgs (1994), p. 283.

${ }^{3}$ In the wake of Adler-Karlsson are Ikenberry, Lake and Mastanduno (ed.) (1988); in its geopolitical dimension this article is aligned with Bonin 2007, pp. 235-254.
} 
For its part, it weighs whether the Cold War altered the norms on which the market economy is based and added additional obstacles to the traditional reluctance of the multinationals to cede technology.

Rather than capricious, this plural outlook conforms to the special nature of the exported goods, a part of which escaped the registry and was excluded from large numbers, thus requiring a vision from the companies. It seeks to refine the approach to economic effects, not limited exclusively to monetary ones. Obviously, it updates the bibliography and incorporates new primary sources, among which the business and official sources of diverse origin and nature stand out.

There are two issues to consider. The first refers to the interference of multilateral organizations in the future of companies based in non-aligned countries. The second is aimed at analyzing the intervention of the US Administration in the dynamics of creating companies outside its borders. In sum, the study deals substantially with the problem created by the technological embargo on an international scale and its repercussions in Spain. This perspective of a country belatedly incorporated into the organizational machinery of export control and chronology are highly significant.

The story is part of an era of profound changes in the international scene, among them technological ones as primordial, and those associated with the liberalization imposed by the Washington consensus. Spain added to this horizon its political change with the transition from the bloody Franco dictatorship to democracy under the successive mandate of the right (UCD, the Union of the Democratic Center) and the moderate left (PSOE, the Spanish Socialist Workers Party). The wave of change was completed by a race to access the European Common Market competitively. Spain, which in 1980 ranked 21st among merchandise exporting countries with $1.02 \%$ of the total, had a relatively low market opening -exports and imports relative to GNP- compared to large countries of its economic area ${ }^{4}$. Regarding the problems that concern us here specifically, Spain shared with Portugal, Italy, Greece and Turkey the category of the so-called southern flank of CoCom ${ }^{5}$.

\section{Geopolitics versus economics: the CoCom}

The Allied victory over Nazism in the Second World War put an end to the understanding between antagonistic economic systems and led to a short-lived confrontation or Cold War, based on the reinforcement of internal cohesion in each of the two blocs of unequal scale, the ideological rearmament and the arms race ${ }^{6}$. NATO (North Atlantic Treaty Organization) on the western side and CMEA (Council for Mutual Economic Assistance) in the east shaped this new stage of rearmament and hostility. The United States set up a complex network of organizations, institutions and legislative norms in the service of defense against the enemy bloc through three key pieces: the Export Control Act (ECA) of 1949, the Mutual Defense Assistance Control Act of 1951 and the Export Administration Act (EAA) of 1979. The ECA was the first formal peacetime recognition of the new security threat and of the need for a comprehensive export control system, subject to three reasons: national security, foreign policy and shortages ${ }^{7}$. The EAA, with its successive amendments and extensions, empowered the Department of Commerce to regulate "dual use" exports, susceptible to military and civilian applications, based on strategic relationships, threats to US national security, commercial practices international and commercial technologies ${ }^{8}$.

\footnotetext{
${ }^{4}$ World Trade Organization 2013, p. 60; Boyer and Drache 1996, p. 38.

${ }^{5}$ Freedenberg 1992, p. 21.

${ }^{6}$ The war had a very different economic impact on the leaders of the two blocs: the strengthening of the US contrasted with the devastation of the USSR: Maier 2010, p. 55. The dominant ideology of world anti-communism, embodied in various foreign policy options, be it Truman doctrine, massive retaliation or Reagan doctrine, led to exorbitant military spending, equivalent to $7.5 \%$ of GDP: Higgs 1994, p. 312.

${ }^{7}$ Aoi 2016, p. 6.

${ }^{8}$ Fergusson 2009, p. 4. The EAA of 1979 established the export control policies of the USA, which involved cooperating with nations committed to the United States in defense treaties in the restriction of exports that would significantly contribute to the military potential of any country that could endanger the US: S.737, 96th Congress (1979-1980). Ronald Reagan declared the state of national economic emergency before the high technology hemorrhage diverted towards the Soviet bloc and signed an executive order extending indefinitely the 1979 EAA, which had expired on September 30: New York Times, 11/27/1983. Prior to the 1985 amendments to the EAA, Congress equated the objectives of trade promotion and national security by weighing the roles of the Departments of Commerce and Defense: Sawchak 1988, p. 787. 
Within a clear propensity for the multilateral organisms, they appear the CoCom -object of our study- and the ChinCom, a committee of China, of independent character, under the advisory group with much stricter controls than those placed on the Soviet bloc ${ }^{9}$. This coalition set up organisms of capture of technology and knowledge, in general linked directly to the authorities and, sometimes, on an exclusively national basis ${ }^{10}$. The CoCom (1949) was a contemporary of NATO and the Berlin airlift, with the mission of coordinating Western export policies towards the eastern bloc under the US aegis. Strictly speaking a 'non-treaty international community of nations', it was composed of all the members of the Atlantic Alliance except Ireland plus Japan and. Its functions consisted in drawing up checklists, granting permits or exceptions to export certain items of the embargoed list and exchanging information about them ${ }^{11}$. Frequent divergences often due to conflicting interests between members occurred indoor, and even confrontations that did not reach beyond, drowned in the opacity and ultrasecretism imposed on national delegations ${ }^{12}$. The angers touched the ignition punctually, as it happened when the US government made the export permits to the United Kingdom (UK) of advanced technology subject to the possibility of accessing the accounts and files of the companies involved ${ }^{13}$.

At the beginning of the 1970s, the effectiveness of the system and its valuable contribution to the success of the deterrence strategy were unanimously recognized, without denying problems in maintaining the cooperation of the other members of the CoCom with the consequent threat to the effectiveness continuous of the system. In general, the US was in favor of maintaining more extensive controls than the CoCom partners, more inclined to reductions in the coverage of the blockade. The difficulties in the multilateral body were exacerbated by the prevailing spirit of detente, the new emphasis on East-West trade and the increasing pressures ${ }^{14}$.

Since the mid-1970s, the US was certain that, the strategic balance could suffer a tipping in favor of the USSR in just a decade if the massive soviet R \& D programs underway achieved the advances they wanted. The USA knew that the relative technological backwardness in some advanced technological areas did not prevent Eastern Europe from supplanting the West as the main source of machine tools for the USSR. There were bags of knowledge where the Eastern European contribution was more significant. This group included electron beam furnaces and the advanced integrated circuits of the German Democratic Republic (GDR), a country with its own network of technology diversion as noted before ${ }^{15}$.

\footnotetext{
${ }^{9}$ Ronald D. Flack Interviewed by Charles Stuart Kennedy, 7/1/1998; Immerman and Goedde 2013, p. 58; Abrahamson [s.a.]. The Department of Commerce was initially stricter than the State Department: Dobson 2003, p. 299; the Pentagon has endowed itself with a specific agency for the control of exports, the Defense Technology Security Administration (DTSA); Defense tended to disapprove exceptions to the Advisory Group (CoCom) lists for the Coordinating Committee against the security of the US and its allies: Department of Defense, Directive 2040.2, 17/1/1984, 1, 5/7/1985.

${ }^{10}$ The Kremlin diverted through the Directorate $\mathrm{T}$ cutting-edge western technology by all means and without paying any attention to costs: Skrubej 2012, s. p. The GDR created Commercial Coordination (KoKo) at the end of the 1960s with the double objective of obtaining foreign currency and of avoiding the obstacles imposed by the CoCom in the achievement of advanced technology. The KoKo, linked in reality to external espionage, wove an unofficial commercial network with the West: Burnett 2007, p. 178. Remember the ties with the State Department, the Defense Department and the Central Intelligence Agency (CIA): New York Times (NYT), 18/3/1996; Bungert et al. (eds.) 2003, p. 101.

${ }^{11}$ Oda (ed.) 1991, p. 32; Donovan 1981, p. 87.

${ }^{12}$ Duncombe 2002, p. 757; Lewis 1990; US: MOD letter to FCO, Thatcher Archives, August 6 1980; reluctance of the UK to restrict trade with the USSR: Cain 1994, pp. 510-522. The CoCom was branded inside and outside the US of 'watchdog' control policy: NYT, 6/1/1985; Le Monde, 25/8/1992.

${ }^{13}$ Council of Europe, Consultative Assembly, Documents, 1986, p. 36.

${ }^{14}$ Foreign Relations, 1969-1976, E-15, 30/1/1973. Different visions of the USA and Europe: Ravenhill 2014, p. 61; US Congress. Senate. Committee on Banking, Housing, and Urban Affairs 1980, p. 161. In the Kissinger era, the operation of the CoCom was considered 'reasonably effective': Memorandum Prepared in the Department of State/1, December 21, 1968. The Department of Defense attributed many of the difficulties to the profound differences between the main US departments and the agencies involved in Washington's decision-making mechanism. The blacklist of the CoCom reproduced in an abbreviated form the Defense, including, in addition to military technologies, computers, software, robots, silicon technology and materials: Pianta 1988. Critical assessment of the CoCom and its failure to counter the Soviet rise as a power nuclear and space: Naylor 1999, p. 37

${ }^{15}$ Interagency Intelligence 1988, p. 1; McDaniel 1993, p. 104; in the GDR, the very advanced Carl Zeiss Jena stood out as a center of excellence.
} 
In their efforts to close the technological gap with the Americans, the Soviets consciously sought to reduce both the closing time and the cost of direct acquisition of advanced Western products and production technology ${ }^{16}$.

The same preference of the Soviets for the finest technology available in the western technological leaders reveals documents of the CIA.

At the beginning of the 1980s, when in a decisive turn to the previous policy of laxity the Ronald Reagan government redoubled export controls in addition to increasing military capacity, it was forced to confirm the achievements of the high technology capture effort carried out by the Soviets ${ }^{17}$. To restrict ourselves to very representative products, in 1970 the USSR had no semiconductor industry, could not even manufacture an integrated circuit. The technological blockade imposed by the CoCom in the 1950s and 1960s had obstructed access to computers. To preserve credibility as a superpower, the only way to effect change was to appropriate North American technology directly throughout the 1970s or indirectly from the next years ${ }^{18}$.

In the assets of the self-proclaimed 'grand strategy', Reagan highlighted the substantial results of his government to curb the flow of strategic technologies to the USSR and its allies ${ }^{19}$. Others have not been so optimistic. The reinforcement of restrictions on exports was a response from the US at the beginning of sales of cutting-edge technology carried out by various countries. However, the effects decreased because of the decline of US leadership in these technologies. Lost total autonomy in control measures, some European countries sought to regroup in defense of common interests. Thus, at the end of the 1980s, France turned to Germany as a guideline of its policies critical of the CoCom rules ${ }^{20}$. Outside of Europe, over the years, the United States has not ceased its efforts to control shipments of sensitive technology to Cuba until the embargo becomes law ${ }^{21}$. In response to the changes in world geopolitics after the fall of the Berlin Wall, the Bush Administration was inclined to improve the exchange of advanced technology merchandise and avoid illegal trade in them. From the organizational point of view, in 1992 the CoCom Cooperation Forum was created to include the new states of the former USSR and other Eastern European countries ${ }^{22}$.

\section{Firms under turmoil}

That enormous fascination of the USSR and its allies for the most sophisticated Western technology fit in the great and growing interest of the US industry in the Soviet market, not always solved by legal channels ${ }^{23}$.

\footnotetext{
${ }^{16}$ Foreign Relations 2014, p. 490 and 496; OFFICE OF THE SECRETARY OF DEFENSE 1985, p. 25; NATO 1984, p. 48; Ministerial Session, 9-10/12/1982.

${ }^{17}$ The budget and resources allocated to prevent the illegal transfer of technology in the Department of Commerce tripled; similar increases were made in the Department of Defense as well as in the customs service: Freedenberg 1992, p. 6.

${ }^{18}$ Stephen D. Bryen, 14/11/1987; Le Monde (LeM), 20/7/1978. Gorbachev alluded in 1989 to the beginning of the demolition of the "internal COCOM", the wall that separated the military and civil goods: History and Public Policy Program Digital Archive, 1990, p. 197-205. Gorbachev's (1986, pp. 55-58) modernizing program emphasized the development of the most cutting-edge economic sectors, microelectronics in a particular way: Interagency Intelligence 1988; CIA, 7327347, NIE 11-7-87, August 1987; SNIE 3/11-4-81, 17/11/1981, U.S. National Archives; "CIA Intelligence Assessment, "Gorbachev's Economic Agenda: Promises, Potentials, and Pitfalls", September, 1985, FOIA request to CIA, National Security Archive.

${ }^{19}$ NSDD 320, 11/20/1988, National Archives; sanctions as a necessary diplomatic weapon: US Department of State Archive, February 25, 2002. The oscillations in the correlation of forces between doves and falcons within the Republican Party influenced political practice; in 1983, the moderates strengthened their positions in the Reagan environment: New York Times, 23/10/1983; in 1983, NATO demonstrated strength against the USSR with advances in the deployment of intermediate-range nuclear missiles: Shultz 2016, np.

${ }^{20}$ Crawford 2013, p. 32; German Economic Minister Says U.S. Pressure For Restrictions Unacceptable, May Retaliate, International Trade Report, 178, 1984. The two major German political parties - Social Democrats and Christian Democrats - shared an opposition to the rules of the CoCom, more radical the first and more moderate the second: Hofhansel 1996, p. 121.

${ }^{21}$ NSDD 235, 8/18/1986, U.S. National Archives. The action in NATO during 1982: "The North Atlantic Council, met in Ministerial Session in Brussels on 9th and 10th December 1982", NATO Archives. The embargo on Cuba indicated the dissenting foreign policy followed by the US and other countries: REF State 78387A-424, Rome, November 23, 1966. Cuba created a ring of at least 25 offshore companies to bypass the embargo: Nuevo Herald, 7/6/2016.

${ }^{22}$ Bush 1993, p. 1.650.

${ }^{23}$ Annual sales of computer equipment from the US to the USSR were estimated at around \$ 100 million: The Public Library of US Diplomacy (TPLoUSD), 6/6/1974. Official estimates attributed to a subsequent smoothing of the regulations increases of "millions and millions of dollars of monthly volume" for North American companies: New York Times, $1 / 1 / 1985$. 
The Cold War set up a global traffic of illegal smuggling of technology to the Soviet bloc, promoted on many occasions from power. The fundamental nodes were located in countries of central and northern Europe, especially those not belonging to the CoCom, including Austria, Switzerland - the Switzerland connection- and Sweden $^{24}$. Many Western countries and Japan regularly violated or circumvented the rules of the CoCom and many members systematically dodged restrictions when faced with conflicting internal issues ${ }^{25}$. The aggregate figures that revealed the deviation of technology in its different aspects become really spectacular ${ }^{26}$.

The diversion of technology to the non-Western bloc is closely linked to sound cases that showed the US failure to contain Soviet efforts to trap the West. Not a few involved companies of great importance and others added new episodes that are indelible to global espionage, such as the Farewell affaire ${ }^{27}$. In the Toshiba case, for example, the US reacted with virulence by negotiating in Congress the ban on all imports of that Japanese company's products $^{28}$. Some, such as that of the German company Imhausen-Chemie even acquired scandal tints (Rabtagate). Imhausen sold equipment and know-how (technical advisors) for the production of chemical weapons to Libya by means of an a well-planned operation camouflaged by the point of departure of the material (Hong Kong as well as other Asian ports) and a ghost company (Pen-Tsao-Materia-Medica-Center Ltd) to hide his real destiny ${ }^{29}$. In fact, Libya enjoyed a 'special relationship' with the Federal Republic of Germany for a long time since, in the 1970s, German MBB engineers created the group Otrag, an engineering company dedicated to the construction of a medium-range ballistic missile in that country ${ }^{30}$. Beyond specific cases, the systematic practice of the so-called techno banditry brought to light sophisticated multinational networks of suppliers, intermediaries, agents and interposed companies that camouflaged the technological products to send them to

\footnotetext{
${ }^{24}$ TPLoUSD registers 5,691 entries for 'customs seizures, electronic equipment'. A double side in the attitude of the USA is showed in the cases of Switzerland and Sweden according to specialists: a use of economic pressure to influence the economic policies of neutral countries and a willingness to compromise in order to avoid undermining other policies of their own, particularly their desire to support non-communist countries and attract them to their orbit: Autio-Sarasmo and Miklóssy 2010, p. 51.

${ }^{25}$ Gregory 1987, p. 867.

${ }^{26}$ In 1967, the KGB sent 1,495 reports, 9,910 materials and 1,403 samples of foreign technology to the USSR, while obtaining 1,376 papers and greater than 330 more recent samples of foreign technology: KGB 1968. North American intelligence experts estimated that since the late 1970s, 30,000 pieces of high-tech equipment and 400,000 technical documents had been smuggled out of the US: Weyhrauch 1986, p. 206. The Soviets acquired more than 2,500 pieces of western microelectronics equipment between the early 1970s and 1980s: Records of the Office of the Secretary of Defense.

${ }^{27}$ Crawford 2013, p. 133; Wrubel 1989, p. 241-273; The Economist, 27/6/1987, p. 66 and 11/7/1987, p. 72; Paradigms, 4, 1, June 1990, p. 74-99; New York Times, 9/10/1989; Rhoades 1989, p. 38. For the Center for Security Policy, the Toshiba case clearly showed little or no control of the country concerned over export permits, inadequate research capacities and enforcement measures: Center for Security Policy, 21/3 / 1989. The Japanese authorities considered the scandal detrimental to the credibility of the country and the North Americans accused the coup: NYT, 3/14/1988. US officials linked Kongsberg/Toshiba's detour to the most famous - and controversial - case of Norwegian espionage (1984) in which Arne Treholt, a senior official of the Ministry of Foreign Affairs and 'young golden' of public life in Norway, was finally prosecuted for passing classified information to the KGB and sentenced to 20 years in prison: New York Times, 29/1/1984 and 9/7/1987.

${ }^{28}$ Toshiba provided the USSR with machinery applicable to the production of more efficient submarines. Sanctions against Toshiba and partners were the subject of several bills at the 100th Congress (1987-1988), along with several amendments. Some highlighted the capricious attitude of the Pentagon to the maneuvers of Kongsberg, who built a sophisticated missile for the US and placed a tenth of its sales in the US Navy: Chicago Tribune, 1/7/1987.

${ }^{29}$ National Academies 1992, p. 33-34; Spiers 1994, p. 65-83. The Rabtagate came to the public thanks to leaks of United States officials: New York Times, 1/1/1989; 1/16/1989; 11/1/1989; 11/5/1989; The German Federal Government disregarded the information of the Federal Intelligence Service (BND) on the German aid in the Libyan production of poisonous gas: Center for Security Policy 1990. For greater abundance, the public company Salzgitter was involved: Stern, 16/1/1989; the amount and diverse origin - North American, European and Japanese - of the network of enterprises involved gives an idea of the magnitude of the case: Timmerman 1990, p. 1: White paper on Libya's chemical warfare program, 1993 December 16, Public Library of US Diplomacy, 93STATE377793_a.

${ }^{30}$ Timmerman 1990, p. 1. Two other German companies -Technical Oil Production and Globesat- participated in the development of Libyan missiles, which also benefited from French and Chinese technology: Cordesman 2016, p. 152.
} 
neutral nations with final destination to the Warsaw Pact and, selectively, to the countries that had a certain role assigned by the $\mathrm{CMEA}^{31}$.

In reality, the North Americans wanted to control the companies and hunt man in order to cover all the channels of transfer in their various forms. In the lists sent by the Department of Defense to its diplomats were engineers and industrialists, who were being vetoed in commercial operations with companies based in the USA.

But the real headache was the innumerable intermediary companies, along with the ghost houses, conceived for a limited number of operations and forgotten afterwards ${ }^{32}$.

\section{Business tactics against the controls of technology transfer}

Firms diversified their responses to the impositions of standards on exports of cutting-edge technology. In general, they bowed to the rules, even considering them excessive and knowing the numerous disadvantages, which ranged from considerable delays in obtaining permits to the outright loss of contracts to other competitors, going through asymmetries in the dissemination of information ${ }^{33}$. The peculiarities of the sector studied here, especially the exposure to an early obsolescence due to the high speed of technological change, accentuated the seriousness of the harmful effects caused by the delays. Manufacturing costs increased due to the obligation to maintain production lines outside the standard. In turn, the procedures for permits and conducting internal investigations in companies augmented operating costs. Given the drawbacks, on numerous occasions the companies decided to challenge the controls and export without being subject to the established standards ${ }^{34}$.

According to a more specific reaction, in the US, companies, spurred by the government, tended to lower the technological level of exports to adapt them to CoCom standards and thus achieve export permits ${ }^{35}$.

In an opposite stance, some increased the sophistication of their shipments in an attempt to dodge controls over sensitive exports ${ }^{36}$. A different pattern was to exclude US technology subject to embargo and replace it with equivalent technology from other sources ${ }^{37}$. Some key US companies even went so far as to exert their control measures to exhibit their patriotism and not lose substantial contracts with the Administration. The controls also had other effects. Some companies gained a comparative advantage over competitors through the transfer of

\footnotetext{
${ }^{31}$ The literature speaks of techno bandits (Melvern et al., 1984) or techno pirates (Discussion paper, 193-197, 1989, p. 60); case analysis in Calvo 2016. Bulgaria played a key role in the distribution of illegal products and services between Europe, the Middle East and Central Asia: Misha 2009, p. 17; Mincheva and Gurr 2013, p. 123.

${ }^{32} J P R S$-WST, 84-005, 7/2/1984. Especially lacerating was the damage caused by the betrayal of former employees of the Administration, who are well acquainted with the transfer mechanisms: NYT, 15/10/1981.

${ }^{33}$ US businessmen accepted controls on articles of military importance but criticized the superior harshness with which the USA applied such controls: US Congress. Senate. Committee on Banking, Housing, and Urban Affairs 1980, p. 161. A pleading against the delays in communicating information to companies about the changes in the CoCom lists, in General Accounting Office (1990), pp. 1-14. Computer firms accused the Administration of betrayal of the spirit of the Export Administration Act: Computerworld, 8/6/1981, pp. 69 and 75. IBM lost the sale of a computer batch in front of the Japanese Hitachi; the press highlighted the disastrous effects of disagreements between government agencies, which favored non-US companies: NYT, 10/18/1987. Sometimes, losses of millionaire contracts threatened the stability of an economy in a situation of fragility: TPLoUSD, 9/2/1974.

${ }^{34}$ Export Administration report: report on U.S. export controls to the President and the Congress. At an average exporter preparation cost per license of less than $\$ 100$, the total burden for companies exceeded $\$ 2$ million: Rasmussen (ed.) 2014, p. 743. The status of subsidiaries of USA companies held by many European companies increases the complexity of the cases. UK and France requested from the CoCom exceptions involving interest competition in the manufacture of central equipment processing units and magnetic tape controllers in Czechoslovakia, concerning Bull/GE: Washington National Records Center, FRC 72 A 6248.

${ }^{35}$ According to a confidential report: "Considerable effort was made to keep technology and equipment at the lowest possible levels and, thus, keep the transaction viable": Fairchild transaction for Tungsram/Hungary, TPLoUSD, 9/10/1976, unclassified.

${ }^{36}$ Allied Signals Garrett Engine Division declined to apply for an export license under the revised EAR Regulations and CoCom controls to modernize the TFE-731-2A-2A: Select Committee of the United States House of Representatives, U.S. National security and military/commercial concerns with the People's Republic of China, 105th congress, 1999.

${ }^{37}$ Worth the outstanding example of Caterpillar Tractor Co., taken up to leadership thanks to trade with the East and forced to reject a request for vehicles for $\$ 200$ million, because of the loss of the Soviet market in favor of its Japanese rival Komatsu Ltd.: New York Times, 23/10/1983; Wakounig 2012, p. 239.
} 
technology implicit in joint ventures agreements or construction contracts for complete plants ${ }^{38}$. There were contrasts at a national level. In the UK, for instance, two different ways of controlling exports in the relations between the Government and companies were opened.

The Department of Industry and Commerce and the exporter often added forces to try to improve the chances of success of the permit application by trying to redefine the category of the CoCom lists. When a request for a license was stopped, the exporters usually reacted with a rejection of the controls because of the delays and the uncertainties that they entailed ${ }^{39}$.

In general, the firmness of the response of the companies was in line with the size of the business concerned. The sanctions against the companies involved in the construction of the gigantic Soviet gas pipeline, for example, revealed Reagan's contradictory policy, caused a real crack in NATO and was sharply criticized by large US companies, which saw the sale of equipment and equipment in jeopardy materials for more than 2 billion dollars ${ }^{40}$.

The requests for exceptions were wishes from companies of member countries to exempt CoCom control of an article whose sale was prohibited from being included in the embargo lists, whose evolution shows high figures in 1951-54 and a drop after. Each member government reviewed all these requests and recommended the decision to take - total or partial approval or refusal - to the CoCom, which, in turn, informed the requesting nation. Decisions had to be taken unanimously. In the US, exception requests from non-CoCom countries, as well as US exporters, were first sent to the Office of East-West Trade of the State Department. The processing of these requests was carried out through the Economic Defense Advisory Committee (EDAC). This implied an interinstitutional review that began in the Working Group I with consultation between representatives of the director level of the office of the State, Defense, Trade, Energy and Treasury departments, with the advice of the CIA. Exception requests grew significantly and almost constantly in the period 1967-1977. We refer, then, to a slow, complex and expensive machinery for companies ${ }^{41}$.

\section{The economic costs: an approximation}

The chosen interdisciplinary approach requires a brief macroeconomic exercise to evaluate the economic costs of control over exports. At that issue, a series of considerations are imposed, the first of which points out the difficulty of defining the scope of high technology ${ }^{42}$. The second one points to undervaluing due to at least four causes: lack of official data of sector and individual companies; data collected by specialized agencies not accounted for; hidden nature of the operations and difficulty of calculating the side effects on future trade, employment, subcontractors and government income ${ }^{43}$.

\footnotetext{
${ }^{38}$ Practice adopted by Digital Equipment (DEC), Burroughs Co., Honeywell Inc. and Sperry Corporation and tried by IBM (NYT, 6/1/1985) and in Europe by Technip. The powerful DEC announced the creation of a joint venture in Hungary, after exploring the market with a mission in three Eastern European countries, from which recommendations were made to its European subsidiary: LeM, 14/2/1990.

${ }^{39}$ Bertsch 1988, p. 220. Example of delays and obstacles to the transfer is offered in 1985 by the French Les Accessoires Scientifiques, subsidiary of the Société Générale, which sent US-made machines to the USSR to produce sophisticated electronic microcircuits; Judgment of the Court of 4 October 1991; "Criminal proceedings against Aimé Richardt and Les Accessoires Scientifiques SNC", Case C-367/89; LeM, 17/10/1987; The Wall Street Journal, 27/1/1988.

${ }^{40}$ Reagan lifted the embargo on grain exports to the USSR: Wakounig 2012, p. 239.

${ }^{41}$ International Security and Commerce Program 1979, p. 157. The constant requests of general exception to the lists, the delays of the United States in responding to them and the actual renewal of the lists were jeopardizing the principle of unanimity on which the CoCom was based: Bureau of Economic and Business Affairs, 15/7/1977. Tightness, disagreements and disappointments during the review of the lists often appear in the declassified documents: TPLoUSD, $10 / 3 / 1975$.

${ }^{42}$ The Administration considered the high-tech industry so difficult to define and so interdependent with other sectors of the economy that a federal policy for regional development based on distinctions between high technology and other sectors would be artificial and possibly misleading: Annual Report to the Congress: Fiscal Year 1984, March 1985, p. 16.

${ }^{43}$ The Department of Commerce observed that the sums of energy technology exports to the USSR rejected in 1981 were not included in the loss forecast for 1982: Foreign Policy Export Controls, 06/27/1983; difficulties of discovering important deviations of technology to the Soviet bloc in the process of issuing an export license: United States Congress 1988, p. 2. 3; some indirect costs (Foreign Policy Export Controls, 27/6/1983, Gavin III 1989, pp. 1-12), such as those resulting from the loss of corporate image due to breach of commitments, are very difficult to quantify.
} 


\section{Insert Figure1}

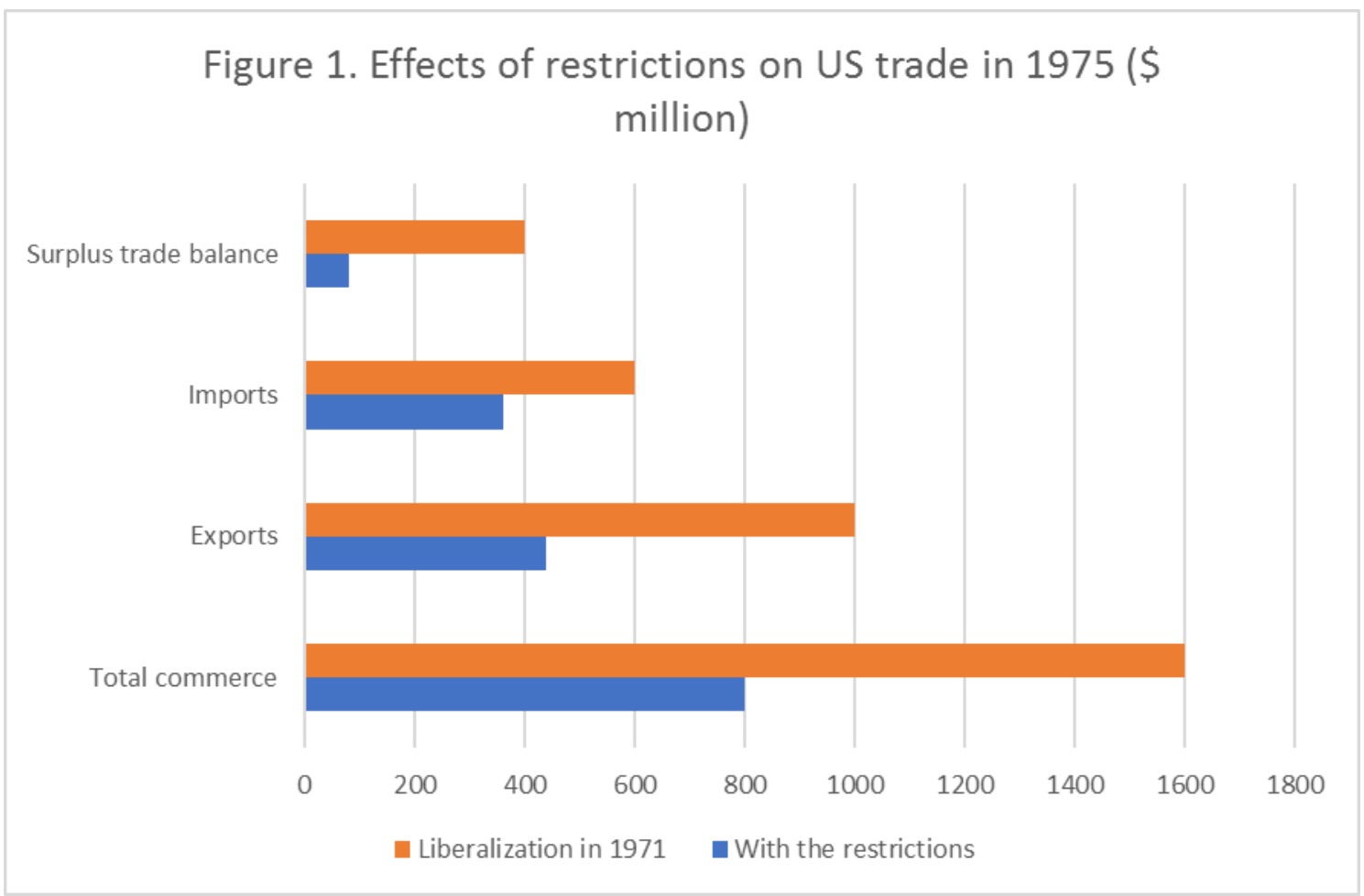

Source: Own from Minutes of a National Security Council Meeting, Washington, October 16, 1981.

Third, controls must be understood in a very broad framework, with notable negative repercussions on the economy (Figure 3). The evaluation of costs should not be limited to considering the effects on technology transfers and should be extended to the additional financial effort derived, essential to maintain the technological leadership against the enemy ${ }^{44}$.The economic impact of control can be placed on a broad approach to the European Union (EU)/US and Eastern Europe trade flows, on the one hand, and trade flows between the two European economic blocs, on the other, with a balance favorable to Eastern Europe (Figure 4).

The EU and the US were economic zones of equal importance with bilateral trade relations, generally balanced and sustained, albeit in an unequal context, fueled by the ambition of US military and political hegemony in Europe. The US, key in the economic organization resulting in the IIWW, worked directly in the European construction through a military instrument - NATO - and a policy aimed at imposing the alignment of Europeans in their foreign policy towards third countries. But the insufficiencies of the EU, an incoherent strategy, the fragility of its economic and commercial power, the incomplete state of the internal market and the foreign trade policy that trivialized the interests of the Union impeded adopting ways to rebalance transatlantic relations. The EU was not ready for the economic war imposed by the US through powerful intelligence and the redistribution of objectives pursued during the Cold War with the result of relentless competition ${ }^{45}$.

\footnotetext{
${ }^{44}$ In the Toshiba case, the cost to the West of restoring the status quo ante was estimated at tens of billions of dollars: Center for Security Policy (1989); over time, the US Government ended up relativizing the effects: $N Y T, 14 / 3 / 1988$.

${ }^{45}$ I follow Lefort 1999 closely; on the EU strategy, see (COM(95)0071 - C40108/95), PE 215.393/def., March 22, 1996. 


\section{Insert Figure2}

Figure 2. The intra-European foreign trade, 1949-1955

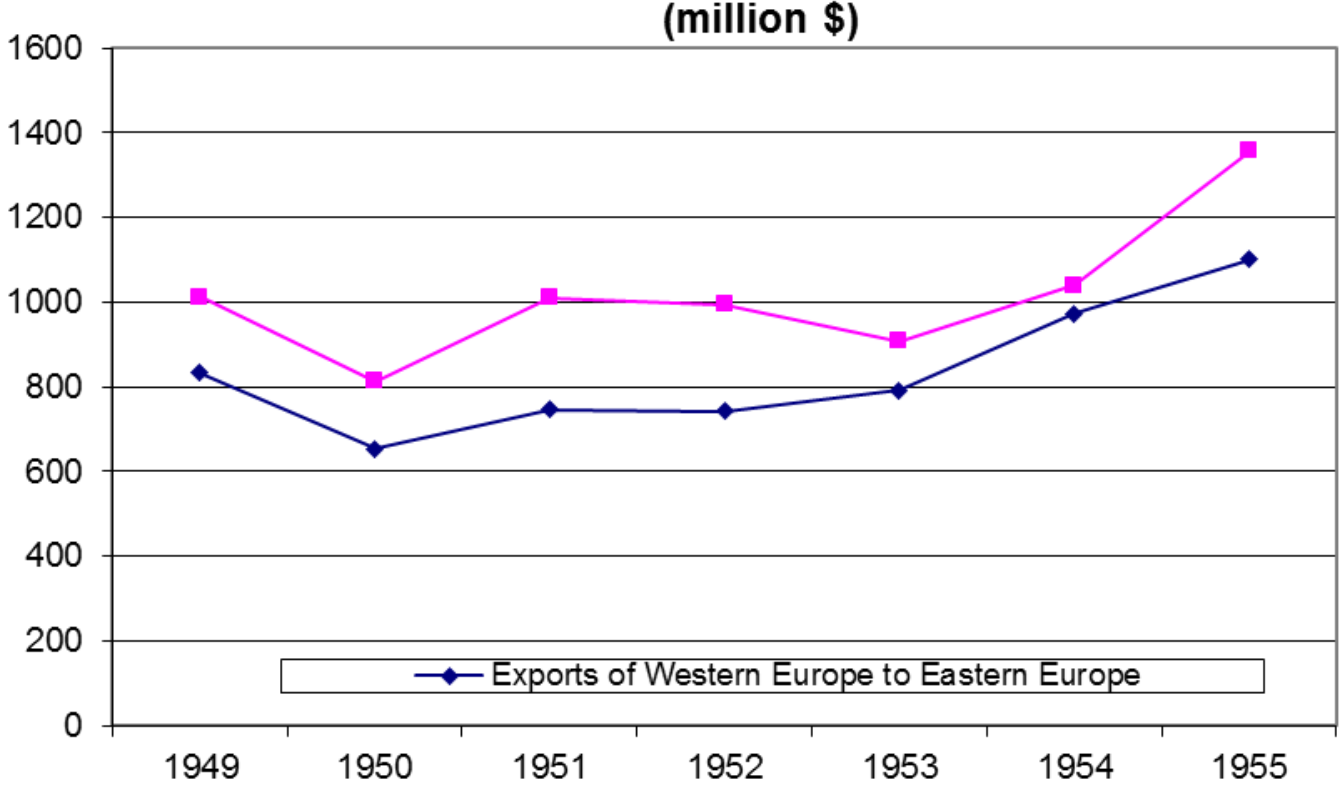

Source:

Own from Adler-Karlsson (1969), p. 46.

The economic impact of the control was subject to valuations with irreconcilable positions in the Administration and the companies ${ }^{46}$. The sources, especially the press, refer usually in generic terms to the high volume of the transfer of advanced technology to the eastern bloc and speak of up to billions of dollars in value of just the hardware ${ }^{47}$. However, the official reports and the specialized agencies provide repeated information to determine the enormous magnitude of the traffic involved ${ }^{48}$. To circumscribe ourselves to an early period, a Memorial to Richard Nixon estimated direct US trade with Eastern Europe in 1969 at less than \$ 240 million and pointed out that the elimination of some existing export controls would slightly improve this trade ${ }^{49}$. What is indicated for Europe applies to all traffic of any type in the USA with third countries under surveillance or embargo and includes, of course, the innumerable direct investments of North American companies ${ }^{50}$.

46 The total liberalization would add in 1975 around one billion dollars to exports and some 400 million dollars to the US trade balance: Memorandum From the President's Assistant for International Economic Affairs (Peterson) to President Nixon, 7/7/1971. "We shot ourselves in the foot," argued the commercial promoters before the negative side of the policies: NYT, 2/9/1983.

${ }^{47}$ The value of thousands of high-tech elements between 1975-1985 diverted by the Soviets totaled billions of dollars: OFFICE OF THE UNDER SECRETARY OF DEFENSE 1985, p. 24-25; in addition, huge sums in defense using US R \& D achievements were saved without any risk: Smits Jr. 1984, pp. 245-277.

${ }^{48}$ The Office of Export Administration stopped twenty shipments for a total value of $\$ 654,184$ and, at its request, the Customs District Directors, a lower-level organism, seized irregular shipments for a total value of $\$ 154,689$. During the same interval, 3,515 export examinations were carried out and 30,269 export declarations were reviewed. Of these, 48 export violations and 597 discrepancies required further investigations: U. S. DEPARTMENT OF COMMERCE, 114th Report on U.S. Export Controls to the President and the Congress Semiannual: April-September, 1976.

${ }^{49}$ Chapman 2013, p. 61.

${ }^{50}$ In mid-1977 there were 491 electronics companies in Korea (including 16 foreign companies): Information on American electronic firms in Korea; 28 US electronics manufacturers were based in Hong Kong, most of them in the local industry, generally occupying four-fifths of the female workforce and facing a constant shortage of skilled labor: TPLoUSD, 9 and 2/5/1978. 
Table 1. Impact of sanctions on US companies on US exports to various countries, 1987 (estimated losses, in \$million)

\begin{tabular}{|l|c|}
\hline Countries & Estimated losses \\
\hline CMEA & 4,649 \\
\hline North Korea & 99 \\
\hline Vietnam & 46 \\
\hline Cuba & 431 \\
\hline South Africa & 329 \\
\hline Angola & 35 \\
\hline Cambodia & 1 \\
\hline Libya & 341 \\
\hline Iran & 857 \\
\hline Nicaragua & 100 \\
\hline Panama & 109 \\
\hline Overall total & 6,997 \\
\hline
\end{tabular}

Source: Own from Hufbauer et al. 1990, p. 33.

The monetary calculation of the effects of the restrictions and sanctions for the whole period is equally difficult to establish. We do have figures for specific years. The Academy of Science estimated the costs for the whole of the US economy in 1985 at 17.1 billion. A substantial part -some more than one third - corresponded to losses of opportunities in the exchanges within the West due to competitive disadvantages for the American companies because of the controls while 1.4 billion were lost in the West-East export sales. In any case, there were no unique explanatory factors for the decline in the global competitiveness of the United States, and export controls could only be significant in some cases. Richardson estimated that export controls cost the US economy about \$ 29 billion in export sales in 1991 because of controls ${ }^{51}$. For its part, the Department of Commerce estimated that $\$$ 2.2 billion of business was lost due to sanctions ${ }^{52}$.

\section{The scope of control of the transfer of high technology: a business perspective}

The massive transfer of advanced technology to the East reflected the involvement of a large number of companies, sometimes illegally. According to reports from the Central Intelligence Agency (CIA), 300 companies from 30 countries were involved in movements to divert high-tech military products sensitive to the Soviet bloc ${ }^{53}$. The thorough enumeration is difficult due to the secrecy of CoCom procedures as a primary instrument of the control system, the enormous diversification of technology transfer channels and the opacity of a multitude of illicit operations ${ }^{54}$. Table 2 offers the composition by sectors from a sample of a hundred companies, which includes the main US operations with the USSR, approximately one third of the total.

51 Kennedy and Southwick 2002, p. 142; National Academy of Science 1987, p. 226; Panel on the Future Design and Implementation 1991, p. 318. The harmful effects were attenuated when they were transferred via prices to the world industry, especially the Japanese and European: InfoWorld, 26/5/1986, p. 30.

${ }^{52} N Y T, 15 / 11 / 1982$.

${ }^{53}$ Many more companies could be involved in only a few operations and disappear or dissolve before becoming vulnerable or discovered: OFFICE OF THE UNDER SECRETARY OF DEFENSE 1985, p. 24-25; Los Angeles Times, 15/4/1985; The Christian Science Monitor, 11/9/1987.

${ }^{54}$ They stand out as transfer modalities: espionage (Overt Collection); illegal trade activities and acquisition by exchange: Cheeseman 1986, p. 1. The illegal diversion of technology came from legitimate channels of commerce to destinations proscribed through foreign companies, agents in situ of foreign companies or foreign subsidiaries of US companies: CIA Archives, June 1982, p. 18. 
Table 2. Composition of U.S. with the Soviet Union by sectors, 1960-1985

\begin{tabular}{|c|c|}
\hline Sector & $\begin{array}{l}\text { Number } \\
\text { of firms }\end{array}$ \\
\hline Energy in general & 3 \\
\hline Atomic Energy & 2 \\
\hline Machine tools & 49 \\
\hline Machinery and Motors & 3 \\
\hline Metals & 7 \\
\hline Electronics & 9 \\
\hline Computing & 3 \\
\hline Building & 2 \\
\hline Motor vehicles & 7 \\
\hline Aeronautics & 2 \\
\hline Chemistry & 3 \\
\hline Agricultural equipment & 2 \\
\hline Bearing equipment & 1 \\
\hline Tool equipment & 1 \\
\hline Oil equipment & 5 \\
\hline Services & 3 \\
\hline No data & 2 \\
\hline
\end{tabular}

Source: Own from Sutton 2014, passim. 
The existence of shipments of strategic equipment by the British, French and Germans was a clamor. Persisting in the effort, it is possible to elaborate a still more incomplete list of the companies involved in sales operations of technology sensitive to the non-western bloc. These are cases of very diverse scope carried out by equally diverse firms, among which some stand out due to their large size -General Electric, Alsthom and AEG- and others, exemplified by Pégard or Olivetti, due to their national impact ${ }^{55}$. Along with the bulk of industrial companies are those of engineering, some of them of great importance for the business figures that drove ${ }^{56}$.

Conveniently used as a representative sample, it provides an approximate overview of the peculiarities of the companies involved in Western high-tech transfer to the Eastern bloc. To begin with the geographical origin, Americans predominated with $43.33 \%$, followed by French with $23.33 \%$ and German with $11.66 \%$. With much less presence were the Italians, Swiss and Japanese.

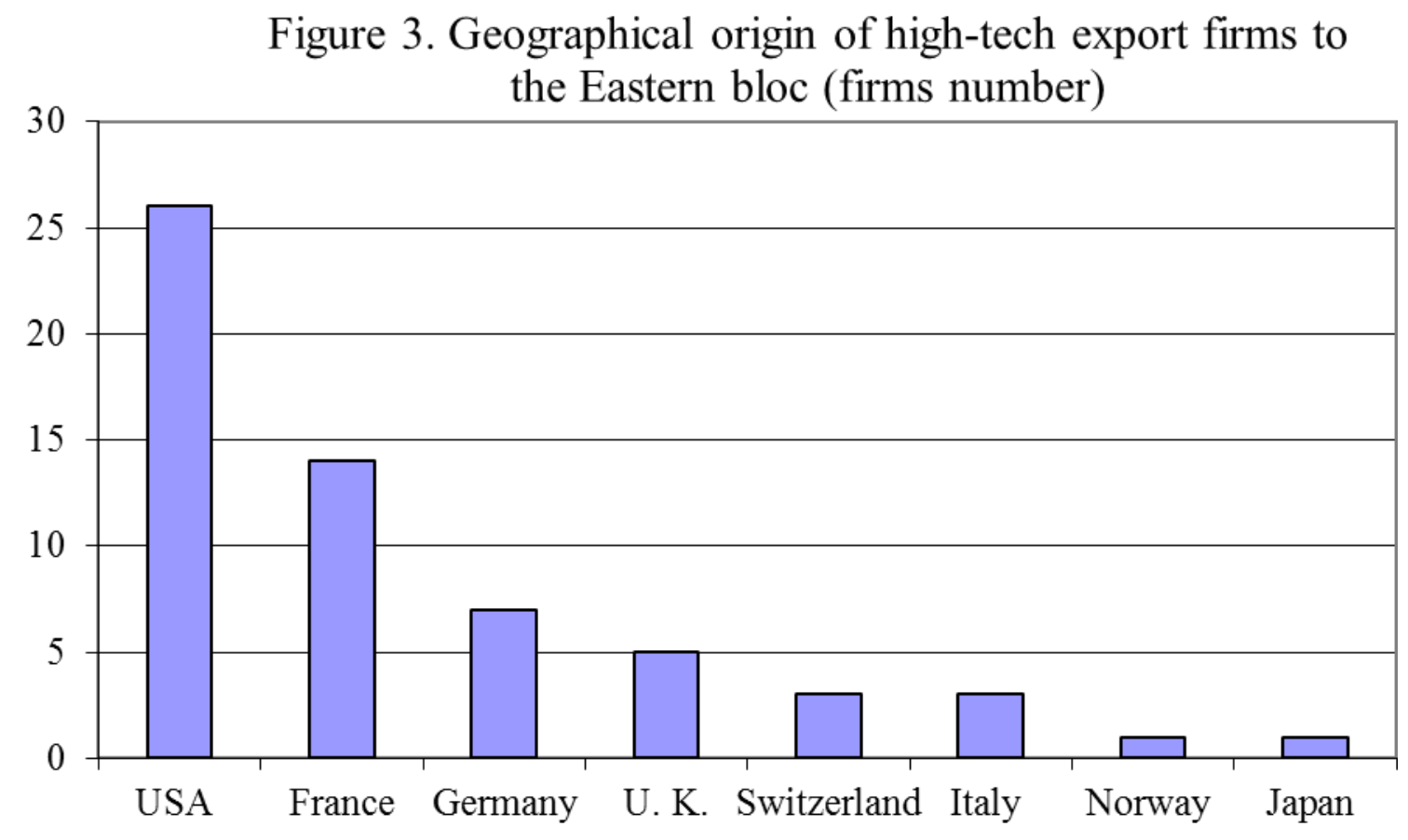

\section{InsertFigure3}

\footnotetext{
${ }^{55}$ In the paradigmatic affair Pégard, the government showed more interest than usual: Roodbeen 1992, p. 89. The Olivetti case, accused of being in dark dealings with the USSR and the KGB, was denied by the Italian Government and magnified by the USA: Il Giornale, 11/08/2005; Bertsch and Elliott-Gower 1992, p. 201. Olivetti tried to counter exhibiting its export licenses and the antiquity of its exports to the East directly or indirectly through commercial offices and agents: $L a$ Repubblica, 10/13/1989; Washington Post, 10/12/1989.

${ }^{56}$ Technip stands out, responsible for building with US technology two petrochemical complexes in the vicinity of the Urals and in Siberia for about 2.5 billion francs; an ethylene oxide plant in Bulgaria or, years later, a gas desulfurization plant in the Caspian Sea region: LeM, 24/12/1976, 2/6/1975 and 18/12/1982.
} 


\section{Figure 4. Exports of western technology to the Eastern bloc (million \$)}

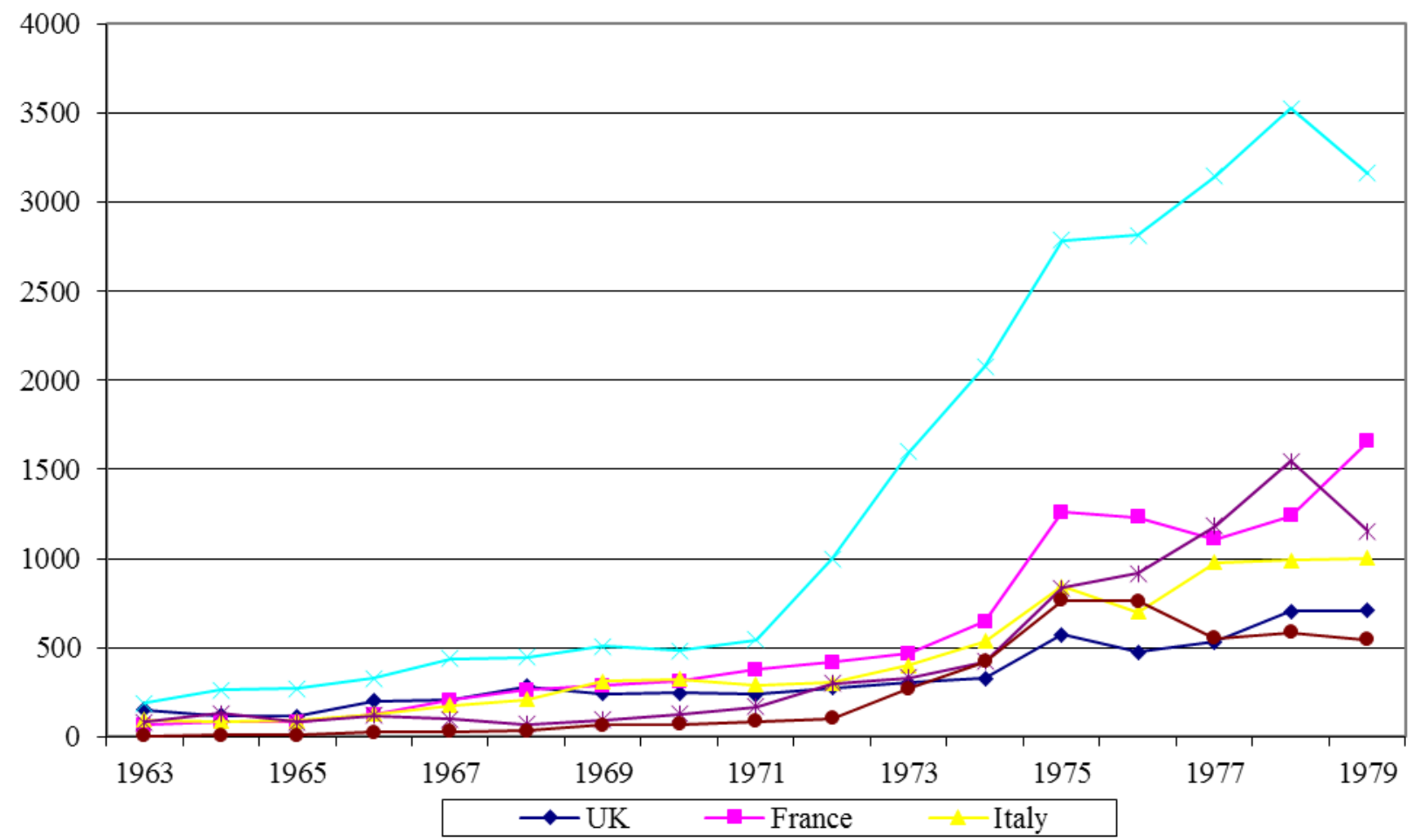

In terms of structure, the ICT and electronics sector predominated with $48.33 \%$ at a distance of twelve percentage points above the machinery, a sector in which Western Europe headed the group of suppliers to the East, at a huge distance from the USA.

Thus, Europe supplied approximately $80 \%$ of the Soviet imports of machine tools of western origin and $60 \%$ corresponded to the FRG ${ }^{57}$. The group that included raw materials occupied residual positions. With a clear change in the head of the ranking-ICT and electronics instead of machinery-the structure bears a strong resemblance to that of US trade with the Soviet Union in 1960-1985, presented above (Table 2).

As for the destination of the transfer, the USSR predominates, the hegemonic power of the bloc, just as the US does in the western bloc. Unfortunately, the lack of complete data does not allow to quantify the total volume of operations, although the partial figures allow to see a high amount. We take for granted the incomplete nature because numerous companies that export sensitive goods are documented, without there being absolute proof that their final destination was the eastern bloc. This category includes Philips Elmet Corp., Antex, Attleboro, Interdata Inc., division of Perkin Elmer and Oceanport ${ }^{58}$.

The shortage of information about certain operations and the extension of some over several years prevent establishing an exact chronology but we can observe a clear concentration in 1982-1983. No doubt that the explanation lies in the relationship with the Exodus Operation of accentuation of the controls and with the construction project of the aforementioned Siberian gas pipeline, precisely one of the most outstanding episodes ${ }^{59}$.

\footnotetext{
${ }^{57}$ Cambier 1985, p. 184. Computers, machine tools and telecommunications added more than three quarters of volume of permits: Meijer 2016, p. 132. In some countries, as it was in the UK, the machine tool industry was experiencing serious difficulties: COCOM list review: IL 1091 -numerical control machine tools, 10/3/1975. The US recalled that its high-tech companies had a trade deficit for the first time in history; the trade balance of the US machine tool industry became in deficit in the second half of the 1970s: General Accounting Office 1990, p. 6.

${ }^{58}$ Total values: Philips Elmet Corp., Lewiston, Maine (3.800\$); Antex Inc., Attleboro, Mass. (2.135 \$); Interdata (220.000 \$): TPLoUSD, 8/4/1978.

${ }^{59}$ The Exodus operation favored the increase in a single year in the number and value of the seizures by almost four and seven, respectively: Congress of the United States 1983, p. 40. To reinforce the international character of the companies involved, let us cite an Italian case: the use of Verson presses of American origin by Italsider in the manufacture of large diameter tubes destined for the USSR: REF State 783872 A-424, Rome, November 231966.
} 
From the business history perspective, the US embargo placed hindrances in the way of European companies associated with the construction of the pipeline and evidenced Europe's technological dependence. Washington expected the lifting of the embargo against the double commitment of Europeans to reduce their dependence on energy in the East for better control of high-tech exports and to reduce credit with preferential rates granted to the CMEA countries ${ }^{60}$.

\section{Spain and the transfer of advanced technology to the non-capitalist bloc}

The rank of the largest non-CoCom importer, after Switzerland, of goods controlled by that specialized agency gave Spain a high probability of re-exporting that type of goods ${ }^{61}$. Within the relatively complex framework of reexports in their route variables and intermediaries, a branch of the world route of diverted technology was called the silicon route. The majority of the Spanish companies with North American technology that re-exported to the Eastern countries were based in Barcelona. The condition of privileged point of Europe, which combined a great business dynamism with insufficient industrial control for the large number of existing undertakings and companies, made the city preferred for the illicit traffic of technology. Sometimes, as in foreign cases, the silicon route had a Central European connection, preferably in Switzerland, a neutral territory in which operations payments were made with great frequency ${ }^{62}$.

The broad perspective of this article claims to take into account not only the physical contents of the technology transfer but also the knowledge. Special attention deserves the geopolitical involvement of technology transfer controls in neutral countries, as was the case in Spain. It is, in particular, the interference of the US Administration in the dynamics of creating a headquartered in Spain joint venture with AT \& $\mathrm{T}$ in the field of microelectronics with USA technology. Precisely, the microelectronics, in unstoppable rise, was among the 'critical' areas whose re-exportation Reagan intended to obstruct precisely because it considered it a powerful instrument of development ${ }^{63}$.

The US demanded adhesion to the CoCom or a bilateral agreement with the US to obtain sufficient guarantees that the transfer of dual-use technologies would not go to the enemy. It was an indispensable condition to give free rein to the investments of AT \& T in Spain against the alternative of the UK, a country committed to an independent national industry of semiconductors ${ }^{64}$. Until Spain joined CoCom, the US did not unlock the creation of a joint venture with US majority capital that manufactured next-generation chips outside the US, named AT \& T Microelectrónica de España ${ }^{65}$.

Possibly the best compendium of the work carried out by Spain within the CoCom lies in a response formulated by the government in the Congress of Deputies. The representative of the Executive identified it with that of any member, that is, participating in the various subcommittees established, particularly in the review of lists and authorization of exports of dual-use technologies. In that, he defended the rationality of the lists through the elimination of technologies that were already of generalized knowledge. In the second, he tried to obtain the authorizations requested by Spanish companies ${ }^{66}$.

From the normative point of view, in 1988 the Subdirectorate General of Foreign Trade Control was created in Spain, coordinating body of the ministries involved (Economy and Treasury, Industry, Defense and Foreign Affairs). A new front opened up between exporting companies and the government, in which discrepancies were detected between the Ministry of Commerce, committed to the promotion of exports, and the Ministry of Foreign Affairs, convinced of the need to adapt to the CoCom's dictates as means of giving Spain access to the high technology of the most advanced member countries. At the beginning of 1990 a control system came into force with the publication in the Official State Gazette of the list of products subject to special license and the creation of a registry of companies dedicated to this trade. ${ }^{67}$.

\footnotetext{
${ }^{60}$ Criticism from conservative positions (Cato Institute): Gavin III 1989, p. 1-12.

${ }^{61}$ Roodbeen 1992, p. 86.

${ }^{62}$ El Periódico, 2/7/1986. Reference to those networks in the US: Federal Register, 47, 42, 3/3/1982.

${ }^{63}$ 19/4/1988, Reagan Archives.

${ }^{64}$ Roodbeen 1992, p. 86; NYT, 5/12/1985. Some countries not integrated into the CoCom, including Ireland, followed the policy of the multilateral organization: Fitzpatrick 1988, p. 249.

${ }^{65}$ Detailed analysis of the case in Calvo 2016.

${ }^{66}$ Congress of Deputies, 184100323/2, July 201990.

${ }^{67}$ Boletín Económico de ICE, April 18-24, 1994, p. 7. The decisive step in the integration of Spain into the Western security system was later completed with the adhesion to other control and non-proliferation regimes, among them the Wassenaar 
It remains to consider the economic impact of the controls on the transfer of advanced technology in Spain, a complicated task due essentially to the dearth of data for the $1980 \mathrm{~s}^{68}$. Let us first point out that, in absolute terms, the economic effect could not be very large since Spanish exports of this category never exceeded $2 \%$ of total exports. Comparatively, the percentage was below the European figures ${ }^{69}$. We do know the figures of Spanish exports of dual-use goods of the following decade, which show a double successive movement of rise in the first half and a tendency to fall later. Difficult behavior could hardly be attributed to the same phenomenon of progressive disappearance of controls or revision of their mechanisms since the end of the Cold War.

There is still a final assessment related to the approach and refers to the need to take into account non-purely quantitative elements regarding the volume of transfers. Unfortunately, the data is not abundant here either, on the contrary. If credit is given to the official calculations, there was a loss of competitiveness for at least a third of Spanish exports, whose monetary scope was estimated at 1.35 billion pesetas ${ }^{70}$. The business perspective allows adding new considerations about the economic impact.

Table 3. Spanish high-tech export companies to the Eastern bloc

\begin{tabular}{|c|c|c|c|c|c|}
\hline Exporterfirm & Year & Destination & Tecnology & Value & Sanction \\
\hline $\begin{array}{l}\text { Pedro Noble } \\
\text { Menhinick }\end{array}$ & 1975 & $\begin{array}{l}\text { Unknown } \\
\text { (outlaw) }\end{array}$ & Fourier analyzer & $237,000 \$$ & blacklist \\
\hline Magnetoflux & 1982 & Bulgaria & $\begin{array}{l}\text { magnetic discs for } \\
\text { computers }\end{array}$ & & blockade \\
\hline $\begin{array}{l}\text { Carlos Mira } \\
\text { Gallart }\end{array}$ & 1982 & East & & & blacklist \\
\hline Comercial RMS & 1982 & East & & & blacklist \\
\hline SICSA & 1982 & East & & & blacklist \\
\hline Fielsa (Madrid) & 1982 & East & & & blacklist \\
\hline $\mathrm{CASA}^{71}$ & & Poland & airplanes & & blockade \\
\hline $\begin{array}{l}\text { Piher } \\
\text { Semiconductores }\end{array}$ & $\begin{array}{l}1979- \\
1982\end{array}$ & Cuba and USSR & $\begin{array}{l}\text { advanced } \\
\text { equipment (Hewlett } \\
\text { Packard) }\end{array}$ & $\begin{array}{l}\text { more than } \\
2 \text { million } \$\end{array}$ & blacklist \\
\hline SUIN $^{72}$ & $\begin{array}{l}1976- \\
1983\end{array}$ & Bulgaria & $\begin{array}{ll}\text { electronic } & \\
\text { equipment } & \text { from } \\
\text { Fairchild } & \\
\end{array}$ & & blacklist \\
\hline CTNE & & USSR & $\begin{array}{l}\text { Carry out the data } \\
\text { transmission } \\
\text { network with } \\
\text { Honeywell } \\
\text { equipment }\end{array}$ & & veto \\
\hline CTNE & 1984 & USSR & $\begin{array}{l}\text { joint } \\
\text { creation }\end{array}$ & & obstruction \\
\hline Ceselsa & 1988 & USSR & $\begin{array}{ll}\text { installation } & \text { of air } \\
\text { traffic } & \text { control } \\
\text { systems } & \\
\end{array}$ & $\begin{array}{l}2,000 \\
\text { million } \\
\text { pesetas }\end{array}$ & veto \\
\hline
\end{tabular}

Notes: The shipments by Pedro Noble Menhinick were aerial following the route: Geneva-Madrid- FrankfurtVienna; SICSA: Servicios Informáticos Condal SA; SUIN: Sociedad de Instrumentación Científica Source: Own elaboration based on the bibliography indicated.

Agreement, heir of CoCom: Cupitt and Grillot 1997. Negative and unanswered requests helped feed Spanish officials the idea that the US was not a genuine or reliable ally: U.S. House of Representatives 1987, p. 16.

${ }^{68}$ Subdirección General de Comercio Exterior 1995, pp. 65-93.

${ }^{69}$ Weighing in the value of industrial exports: machinery and mechanical equipment: $8 \%$; office machinery and computers: 3.9\%; Electrical and electronic machinery: 5\%: Etxezarreta 1991, p. 484.

${ }^{70} A B C, 10 / 5 / 1988$, p. 19.

${ }^{71}$ In 1979, seven years after joining Airbus Industrie, G.I.E., the participation of Construcciones Aeronáuticas S.A. (CASA) in the consortium was 4.2\%: U.S. International Trade Commission (1993), pp. 2-14.

${ }^{72}$ SUIN undertook to submit to the monthly inspection by any representative of the North American government for two years the equipment received from the Californian Computer Automation. The source allows to identify the market, formed by Standard Eléctrica, Amper, Telettra España, Citesa and Secoinsa, among several other: SUIN SA, PLoSD, 21/12/1977. 
A long and patient work of gleaning in diverse sources has brought out a dozen companies related to the transfer of technology to the East (Table 3). Compared to the list of companies from other countries presented in the corresponding table, it seems that it is a significant list. Other cases are added to it, indicated by the insufficiently documented secondary sources, namely Photovox SA, Ingeniería Eléctrica y Telecomunicaciones (Inelco, Electrical Engineering and Telecommunications), Iluco, and Famjsa ${ }^{73}$.

Let's focus on a particular case and analyze to begin the Piher one, an emblematic company in the sector. Created in 1949 - contemporary, therefore of the CoCom -, in order to self-supply of components for radio devices, it quickly reached thirty workers. The increase in activity in its production and sales lines led it to move from temporary premises to a new plant.

Piher faced a mixture of problems when it came to focusing his expansion. Although beneficiaries of government regulations required significant measures of local content in imported products, the quasi-monopoly regulator had confined the company to the domestic market. Overcoming such a limitation required an innovative approach, which was reflected in the in the production of goods protected by the state and the cheapness of the workforce. As a non-technological or commercially advanced country, Spain saw this comparative advantage threatened by the profound changes that were taking place in the international division of labor. Given this panorama, Piher endeavored to invest in research and development to achieve processes of industrial excellence capable of competing in the world market. Its exports increased by 70\% during the first six months of 1973, from 262 to 465 million pesetas ${ }^{74}$.

The US authorities included Piher in the denial orders, a blacklist of companies banned from accessing advanced technology from the United States, and imposed a commercial blockade, temporarily denying export permits ${ }^{75}$. An immediate damage was the exclusion of Piher from the compensation program of the FACA (Future Combat and Attack Plane) due to pressure from the US on the Spanish authorities ${ }^{76}$.

But the most interesting thing here is the contribution of this modest example to the full knowledge of the scope of the economic impact, an exercise that must take into account the situation that crosses a company or a specific industrial sector, as we have indicated above. Among the government projects, Piher entered as the backbone of a second less sophisticated technology factory with a company, backed by a research center. After successive plans with the public sector and with multinationals - the Japanese Hokuriku Denki, interested in becoming a member-, suspended payments, finally entered into conversion and was partially acquired by the Spanish Government. The remaining companies of the Piher group ran the fate of Piher Semiconductors S. A. Far from our purpose the temptation of a reductionist exercise attributed to the controls of the transfers of advanced technology in a peripheral country the final destination of a company. However, it does seem that they played a nontrivial role ${ }^{77}$.

To finish, quite possibly the analysis of the impact of the controls requires certain finesse. In a new case, the application of the North American veto to the installation of air traffic control systems by Ceselsa, a private electronics company, which along with the public Inisel served as the basis for the creation of the current Indra, did not prevent the company's exports from growing but they could have mitigated the rate of growth of outlets to foreign markets.

\section{Conclusion}

This article has analyzed the impact of controls on product movements and the transfer of intangible assets between opposing economic blocs in a short period of time during the Cold War period. To begin, it clarifies from the primary sources the assumptions on which the main contributions of the specialists in the matter are based. In turn, it does so from a position that demarcates ideology and facts: the evaluation of policies and their effects is far from the ideological trench opposed to state intervention in the economy.

\footnotetext{
${ }_{74}^{73}$ Cambio 16, 709-721, 1985, p. 56.

${ }^{74}$ De Velasco 2009, p. 55; Guillén 2005; Tosses 2000, p. 55-64. In 1972, the value of Piher's semiconductor production was \$165,000: Electronic components, 1974, p. 143.

${ }^{75}$ Federal Register, 47, 3/3/1984, p. 9.044; the denial order of export privileges of February 25, 1982 was modified by exception: Case No. 626, Federal Register, 49, 246, 20/12/1984, p. 49.490.

${ }^{76} E I P, 13 / 5 / 1983$; Technoproimport was the recipient of a shipment of accessories and automatic processing systems of Xynetics (total value: 270,798 dollars), export license issued to Intertrade Scientific, Xynetics distributor); in Hamburg, the outstanding agent Mueller commissioned and paid for the systems: PLoUSD, 17/9/1976.

${ }^{77}$ Calvo 2016. 
The copious empirical evidence provided has made it possible to advance in the general knowledge of an issue that is very much cultivated by the bibliography but with gaps in the business perspective and in the geographical scope due to the absence in the studies of countries that, despite their minor importance, result when least significant.

The mechanisms, implications and effects on a western country of the North American system of control of the transfers of advanced technology and knowledge are shown. The empirical evidence displays to what extent the US subordinated to its imperial policy the functioning of the market economy, interfering in normal international relations with the subsequent threat to market freedom, conditioning entrepreneurial initiatives on geopolitical grounds, sometimes undermining the competitiveness of certain companies, among which were precisely some of the most dynamic in these sectors, and putting on the edge of the abyss the existence of them. Ultimately, the CoCom agglutinates episodes that appeared as separate and without any relation to be developed in different areas, that is, in the exports of technology the one and in the transfer of knowledge the other. In short, the Cold War introduced distorting mechanisms of the market economy altering the principles on which it is based and added additional obstacles to the traditional reluctance of the multinationals to cede technology. The study certifies with no less copious evidence the validity of Buesa's thesis on the control of international exchanges of weapons and dual-use technologies as a variant of protectionism and an instrument for maintaining economic supremacy and western technological leadership.

At the same time, the study coincides with the central contribution of Segreto (2006) on the persistence of purely national interests under the umbrella of CoCom. Over Europe gravitated a deep asymmetry by the different magnitude that had the commercial flow with the East with respect to the USA. In this sense, Spanish companies charged with a differential of negative repercussions of the absurd mechanisms of the CoCom due to the great weight of the SMEs -more vulnerable- in the business structure. These were faced with a hostile institutional framework without having, for a time at least, the defense mechanisms available to member countries. Even ignoring many of its aspects, there was state intervention in defense of Spanish companies but presumably well below the intensity shown by counterpart governments.

Some of the most significant cases could be used as a pretext to corner competitive companies in markets considered "natural" by the USA. It is logical to think that it could act as a deterrent in projects to go abroad of other companies.

\section{Origin of primary sources}

Archive of European Integration.

Archive of SEPI (INI), Madrid.

Central Intelligence Agency (CIA) Archives.

Congreso de los diputados, Madrid.

Foreign relations of the United States, 1964-1968, Western Europe.

NATO Archives.

Public Library of US Diplomacy (PLoUSD).

Reagan Archives.

Telefónica, Madrid.

The Association for Diplomatic Studies and Training Foreign Affairs Oral History Project.

Thatcher Archives.

U.S. National Archives.

Washington National Records Center.

Woodrow Wilson International Center.

\section{References}

ABRAHAMSON, Sh. R. The role of intelligence in the U.S. and multilateral trade control programs. Center for the Study of Intelligence, 8, 2, CIA Archives.

ADLER-KARLSSON, G. Western economic warfare 1947-1967: a case study in foreign economic policy. Stockholm: Almqvist \& Wiksell, 1968.

AOI, Tamotsu. Historical Background of Export Control Development in Selected Countries and Regions. Tokyo: International Security Trade Control Department, Mitsui, 2016. 
ASGHARI, M., "National Security and Economic Growth", 21, 4, Autumn 2017, pp. 905-924.

AUTIO-SARASMO, Sari and MIKLÓSSY, Katalin (ed.). Reassessing Cold War Europe. London: Routledge, 2010.

BARNETT, H. J., "Research and Development, Economic Growth, and National Security", The Annals of the American Academy of Political and Social Science, 327, January, 1960, pp. 36-49.

BERTSCH, G. K. Export controls in transition: perspectives, problems, and prospects. Durham NC: Duke University Press, 1992.

BONIN, Henry. Business interests versus geopolitics: The case of the Siberian pipeline in the 1980s. Business History, 2007, 49, 2, pp. 235-254.

BOYER, Robertand and DRACHE, Daniel. States Against Markets: The Limits of Globalization. London: Routledge, 1996.

BUESA, Mikel. El control de los intercambios internacionales de armamento y tecnologías de doble uso: el caso de España. IAIF, 19, 2000.

BUNGERT, H. et al. (ed.). Secret Intelligence in the Twentieth Century. Portland: Frank Cass, 2003.

BUSH, George. Public Papers of the Presidents of the United States: George Bush, 1992-1993. Washington: Office of the Federal Register, 1993.

CAIN, Frank, Exporting the Cold War: the British Responses to the USA Establishment of COCOM, 1947-1951. Journal of Contemporary History, 29, July 1994, pp. 510-522.

CAMBIER, Sonia. Aspects politiques et économiques de l'Affaire Pégard. Brussels: U.L.B., 1985.

CHAPMAN, B. Export Controls: A Contemporary History. Lanham Md: University Press of America, 2013.

Center for Security Policy. Alcatel's Soviet Joint Venture: A Sale The West Cannot Afford To Make. March 21, 1989.

Commission of the European Communities. Proposal for a Council regulation on the control of exports of certain dual-use goods and technologies and of certain nuclear products and technologies. Brussels, August 31, 1992.

Congress of the United States. Technology and East-West Trade: An Update. Washington: Office of Technology Assessment, 1983.

CORDESMAN, Anthony H. After The Storm: The Changing Military Balance in the Middle East. London-New York: Bloomsbury Publishing, 2016.

CRAWFORD, B. Economic Vulnerability in International Relations: East-West Trade, Investment, and Finance. Nueva York: Columbia University Press, 2013.

CUPITT, R. T. and GRILLOT, S. R. COCOM Is Dead, Long Live COCOM: and Change in Multilateral Security Institutions. Cambridge Mass: Cambridge University Press, 1997.

Department of Homeland Security. Export control challenges associated with securing the homeland. Washington: Committee on Homeland Security and Export Controls, 2012.

DE VELASCO, L. El proceso de internationalization de la empresa española y el apoyo oficial: un recuento. Información Comercial Española, 849, 2009, pp. 55-64.

DOBSON, Alan P. US Economic Statecraft for Survival, 1933-1991: Of Sanctions, Embargoes and Economic Warfare. London: Routledge, 2003.

DONOVAN, Christopher J. The Export Administration Act of 1979: Refining United States Export Control Machinery. Boston College International and Comparative Law Review, 77, 1981.

ETXEZARRETA, Miren. La reestructuración del capitalismo en España, 1970-1990. Barcelona: Icaria, 1991.

EU Economic and Social Committee. Relations between the European Community and the United States. Brussels: The Committee, 1983.

FITZPATRICK, D. J. Of Ropes, Buttons, and Four-by-Fours: import sanctions for violations of the COCOM agreement. Virginia Journal of International Law, 29, 1988, pp. 247-288.

Foreign Relations, 1969-1976, XXXV. Washington: United States Government Printing Office, 2014.

FRANK, N. K., Export Controls on High Technology. Santa Clara High Technology Law Journal, 105, 1987.

FREEDENBERG, Paul. The MIT Japan program. COCOM in a period of change. Cambridge Mass: Massachusetts Institute of Technology, 1992.

General Accounting Office. Report to the Chairman, Subcommittee on International Economic Policy and Trade, Committee on Foreign Affairs. Advising U.S. Business of Policy Changes. House of Representatives, GAO/NSIALbSO-201, May 1990. 
GAVIN III, J. G. Economic Sanctions: Foreign Policy Levers or Signals? Policy Analysis, 124, November 7, 1989, pp. 1-12.

GOODMAN, R. and LAWLESS, M. Technology and Strategy: Conceptual Models and Diagnostics: Conceptual Models and Diagnostics. New York: Oxford University Press, 1994.

GORBACHEV, M. S. Remarks on US-USSR trade. Harvard Business Review, 1986, 64, 3, pp. 55-58.

GREGORY, Joseph Edward. Controlling the Transfer of Militarily Significant Technology: COCOM After Toshiba. Fordham International Law Journal, 11, 4, 1987, pp. 861-863.

GUILLÉN, Mauro. The Rise of Spanish Multinationals: European Business in the Global Economy, Cambridge Mass: Cambridge University Press, 2005.

Hearings before the subcommittee on European affairs of the committee on foreign relations United States Senate on United States policy toward east Europe, west Europe, and the Soviet Union, 12-13 September 1985. Washington: U.S. Government Printing Office, 1986.

HIGGS, Robert. The Cold War Economy: Opportunity Costs, Ideology, and the Politics of Crisis. Explorations in Economic History, 31, 1994, 3, pp. 283-312.

IKENBERRY, G. John, LAKE, David A. and MASTANDUNO, Michael (eds.). The State and American Foreign Economic Policy. Ithaca: Cornell University Press, 1988.

Interagency Intelligence. Soviet Technology Development Memorandum. Secret, N1 IIM 88-10003/1, March, 1988.

International Security and Commerce Program. Technology and East-West trade. Office of Technology Assessment, Washington: US Government Printing Office, 1979.

KGB.1967 Annual Report, May 6, 1968, History and Public Policy Program Digital Archive, TsKhSD f. 89 (orig.: Russian State Archive of Contemporary History).

JONES, Scott and KARRETH, Johannes. Assessing the Economic Impact of Adopting Strategic Trade Controls. U.S. Department of State, Bureau of International Security and Non proliferation Office of Export Cooperation, December 2010.

LEWIS, Rand C. COCOM: An International Attempt to Control Technology. The DISAM Journal, Fall, 1990, pp. 66-73.

MACDONALD, Stuart. Technology and the tyranny of export controls: whisper who dares.New York: Springer, 1990.

MACRAKIS, Kristie. Seduced by Secrets: Inside the Stasi's Spy-Tech World.Cambridge Mass: Cambridge University Press, 2008.

MAIER, Charles S. The world economy and the Cold War in the middle of the twentieth century, in LEFFLER, Melvyn P. and WESTAD, Odd Arne (eds.). The Cambridge History of the Cold War. Cambridge: Cambridge University Press, 2010. pp. 44-66.

MCDANIEL, D. E. United States Technology Export Control: An Assessment. Westport CT: ABC-CLIO, 1993.

MELVERN, L. et al. Techno-bandits: how the Soviets are stealing Americas high-tech future. Boston: Houghton Mifflin, 1984.

MEIJER, Hugo, Trading with the Enemy: The Making of US Export Control.Oxford University Press, OxfordNew York: 2016.

MINCHEVA, Lyubov Grigorova and GURR, Ted Robert. Crime-Terror Alliances and the State. New York: Routledge, 2013.

National Academy of Science. Balancing the National Interest: National Security Export Controls and Global Economic Competition. Washington: National Academies, 1987.

NAYLOR, R. Thomas. Economic warfare: sanctions, embargo busting, and their human cost. Boston: Northeastern University Press, 1999.

ODA, Hiroshi (ed.).Law and Politics of West-East Technology Transfer. Dordrecht: Martinus Nijhoff, 1991.

Office of Microelectronics and Instrumentation. A Competitive assessment of the U.S. semiconductor manufacturing equipment industry. Washington: U.S. G.P.O., [1985].

OFFICE OF THE SECRETARY OF DEFENSE. Soviet Acquisition of Militarily Significant Western Technology: An Update. Washington: OSD, 1985.

Overview of U.S. international competitiveness: hearings before the Subcommittee on International Economic Policy and Trade of the Committee on Foreign Affairs. House of Representatives, Ninety-seventh Congress, March 19, 1981; June 9; August 11, 1982. 
RAVENHILL, J., Global Political Economy. Oxford: OUP, 2014.

RHOADES, W. E. COCOM, technology transfer and its impact on national security. Thesis, Naval Postgraduate School, Monterey CA, 1989.

SHULTZ, George P. Learning from Experience, Stanford: Hoover Press, 2016.

SEGRETO, Luciano. East-West Trade in Cold War Europe: National Interests and Hypocrisy, In TONINI, A. (ed.), Towards a New Europe. Identity, Economics, Institutions: Different Experiences. Florencia: Polistampa, 2006.

SAWCHAK, M. W. The Department of Defense's Role in Free-World Export Licensing under the Export Administration Act. Duke Law Journal, 1988, pp. 785-817.

SMITS Jr., William H.T. Transfer of high technology from the United States to the soviet bloc: A public policy issue. International Journal of Public Administration, 6, 2, January 1984, pp. 245-277.

SPIERS, E.M. Rabta: A Case Study in International Action, en Chemical and Biological Weapons. London: Palgrave Macmillan, 1994, pp. 65-83.

Subdirección general de comercio exterior, Informe sobre el comercio exterior español de materia de defensa y de material de doble uso. Boletín Económico de ICE, 2.478, 1995, pp. 65-93.

SUTTON, A. The best enemy money can buy. Nevada: Dauphin Publications, 2014

TIMMERMAN, Kenneth R. Western suppliers of unconventional weapons and technologies to Iraq and Libya. A Special Report. Los Angeles, Ca: Simon Wiesenthal Center, 1990

TOSSES, C. PIHER: Expansió I crisi. Una empresa del periode industrial de la postguerra. Carrer dels arbres, 11, 2000, pp. 55-64.

U.S. Department of Justice. Annual Report of The Attorney General of The United States 1986. Washington: National Institute of Justice, 1986.

U.S. House of Representatives. United States Political-military Relations with Allies in Southern Europe: Report of a Staff Study Mission to Portugal, Spain, Greece, and Turkey, October 15-30, 1986, to the Committee on Foreign Affairs.Washington: U.S. Government Printing Office, 1987.

U.S. International Trade Commission. Global Competitiveness of U.S. Advanced-Technology Manufacturing Industries: Large Civil Aircraft. Washington: U.S. International Trade Commission, 1993.

WorldTradeOrganization, World trade report 2013, Petaluma CA: WTO, 2013.

WEYHRAUCH, Bruce B., Operation Exodus: The United States Government's Program To Intercept Illegal Exports of High Technology. 7 Computer L.J. 203, 1986.

WRUBEL, W. A., The Toshiba-Kongsberg Incident. American University International Law Review, 4, 1, 1989, pp. 241-273. 